\title{
Uncontrolled metropolises
}

\section{ERMINIA MARICATO}

\section{Introduction}

7 HE GIGANTIC size of the metropolises of undeveloped capitalist countries has inspired theories that, when trying to explain the specificities of this process have resorted to concepts such as "swelling", "macrocephaly" and "imbalance" resorting, as often seen in academic literature, to a comparison with the situation suggested by the network of central capitalist countries. In the 1970s, a collection of texts organized by Manuel Castells entitled Imperialismo y urbanización en America Latina brought together Latin American authors, in addition to the Spanish organizer, to reflect on the characteristics of this urbanization process. This effort followed the path opened up by the Economic Commission for Latin America and the Caribbean (ECLAC), which sought to reflect on the conditions of underdevelopment in the subcontinent and ways to overcome them. ${ }^{1}$ One of the central issues in the book refers to the difference between the importance of the industrial sector and the "service" sector in the metropolises of the two groups of nations, i.e., Central America and Latin America. According to some interpreters, in Latin American metropolitan areas the "service" sector has absorbed (or received) a much larger workforce, and therefore has been characterized as swollen and related to marginal or backward activities, detached from the hegemonic core, which at that time began to be spearheaded by international capital cities that produced durable goods (cf. Arantes, 2009).

In the countercurrent of a dualistic and schematic view of this concentrated urbanization process, a successful intellectual effort involving numerous Brazilian researchers succeeded in advancing an explanation that encompassed the entire social, economic, political and cultural process as a contradictory unit, which would be the product of an "uneven and combined" process or of "the modern development of backwardness" or yet of "conservative modernization". Based on the main interpreters of Brazilian society - Caio Prado, Sergio Buarque de Holanda, Raimundo Faoro, Celso Furtado, Francisco de Oliveira, Roberto Schwarz and Florestan Fernandes among others - urban planners, geographers, sociologists, lawyers and engineers engaged in the effort of transforming the built environment, incorporated the territory into this approach by analyzing the production of the city and, in particular, the functionality of the informal, illegal or peripheral city to the process of capital accumulation in non-hegemonic countries. The issue of real estate income, which is critical in general capitalist urbanization processes, acquires particular aspects and absolute centrality in the 
peripheral universe (Maricato, 2011). Patrimonialism, privatization of the public sphere, clientelism and the politics of favors, besides the legacy of slavery, the discredit of labor and the incorporation of advances still attached to backward methods are still at the base of the Brazilian metropolis that is experiencing significant transformations - from the changes that led the country to become an internationally important player - but without changing its characteristics of extreme inequality, as we shall see.

The task of developing an urbanization theory on the periphery of capitalism is far from yielding satisfactory results, as evidenced by the unfailing and ubiquitous models of urban and architectural projects brought from abroad by any ruler du jour or the local media, strongly submitted to cultural mimicry. But it should be recognized that the academia has succeeded in swimming against the stream and the development of critical thinking on the peripheral city has accumulated a certain intellectual output linked to an engagement in the search for alternative public policies. ${ }^{2}$

The acceleration and concentration of urbanization in some large clusters, which was not restricted to Latin America, characterized a global phenomenon that would occur more often in the following decades. Among the 49 largest cities in the world in 1890, 42 were in the so-called First World, while seven were in the Third World. Among the 50 largest cities in the world in 2000, eleven were in the First World and the others in the undeveloped or emerging world. This trend increases especially as a result of late urbanization in Asian and African countries, notably China and India. Estimates indicate that Asia may have 10-11 cities with population over 20 million by 2025 (Davis, 2006).

Although, in general, poverty measured by national indicators decreases with urbanization, the absolute number of slum dwellers is growing faster than the urban population (UN-Habitat, 2010). The concentration of poor people in gigantic slums - with overcrowded and unhealthy households, no drinking water, no sewer and garbage collection and with low employment rates and high levels of violence shows a qualitative aspect that distinguishes it from dispersed rural poverty. They are true socio-ecological bombs. In 2005 there were at least 13 slums with over one million people in cities all over the undeveloped world (ibid.).

The counterpoint to the urbanization of poverty - the growth of outlying or slum areas - lies in so-called urban sprawl, responsible for the development of the typical American suburbs that can also be seen in the cities of countries on the periphery of capitalism, sharing the surrounding of region-cites with lowincome irregular occupation. The impact of globalization on cities around the world - due to the "new poverty" and, why not, the new wealth - has been responsible for some changes in the character of segregation as a result of enclaves, ghettos, citadels, condominiums (Marcuse, 1997; Matos, 2004; Ribeiro, 2004; Cáceres \& Sabatini, 2004; Cobos \& Lopez, 2007; Reis Filho \& Tanaka, 2007).

The productive restructuring of capitalism, stared in the 1970s, led to 
changes in the production processes of the built environment (Harvey, 1992; Benko \& Lipietz, 1992; Diniz, 1993; Cano, 1995; Brandão, 2007; Moura, 2010). Expanded metropolization, fragmentation, dispersion, region-cities, urban corridors, urbanization of the archipelago and "post-urban" spaces are concepts that attempt to define the expansion of urban occupation in the territory (UN-Habitat, 2010; Ribeiro, 2004; Veltz, 1996). Some studies seek to define a new role for the metropolis in the globalized world dominated by financialization and new information and communication technologies: global cities, meta-cities, informational cities (Sassen, 1998; Ascher, 1995; Castells, 1999). Intra-urban relations have changed, especially in the articulation between the real estate and the financial spheres, a phenomenon that is more typical of central countries that contributed to setting off the global crisis in 2008 (Harvey, 2005).

These theories, which according to the historical tradition of cultural subordination influence the academic production on cities on the periphery of capitalism do not resist empirical observation and require greater caution when applied. The urbanization of humanity predicted by Henri Lefêbvre in his book The Urban Revolution released in 1970, no longer accepts seeing the city as a "relatively limited and distinct place" since, under the circumstances, it is a "widespread planetary condition", which is demanding a theoretical revision (apud Brenner, 2010, p.26). However, although there is evidence of changes in cities and metropolitan areas on the periphery of capitalism, one cannot say that these changes are structural or deep, although global and Brazilian capitalism has changed significantly (Ferreira, 2007; Moura, 2010; Holanda, 2010). New location and logistics, innovative industrial activities, expansion of communication, financial and educational services, regional urban clusters linked to the production and export of commodities are some of the characteristics that favor the "winning regions" in the concept of Benko \& Lipietz (1992). The changes - which Diniz (2001) called "concentrated deconcentration" - have not prevented concentration from deepening and regional inequalities and disparities from growing.

The capitalist transformations, coupled with decades of neoliberal thinking (in Brazil in 1980, 1990 and 2000) had a strong impact on cities. Deregulation - of what was already not very regulated, such as the real estate market, plus unemployment, competitiveness, tax war, abandonment of social policies in areas such as public transportation, privatization of public services, strategic planning and urban marketing among others, were combined with a historical tradition of lack of control over land use and spatial and urban segregation. Inequality continues to reign sovereign, based on an ambiguous pattern of law enforcement relating to land - in spite of the new federal legal framework - and of investment, both deeply regressive in their social aspects and guided by the interests of the real estate capital in the case of buildings, and heavy construction 
capital in the case of urban infrastructure, whose top priority is the road-centric matrix and, more precisely, the automobile.

Violence in metropolitan areas was consolidated in an unprecedented way in the period mentioned, as evidenced by the increase in homicide rates, which only at the end of the first decade of the twenty-first century began to show signs of reversal, though surrounded by controversy. Tragedies caused by floods and landslides are becoming increasingly common and frequent year after year (Saldiva et al., 2010). The illegal occupation of the edge of streams, unstable deforested hillsides, mangroves, dunes and areas of water source protection is proof that a large portion of the population has been abandoned to their own ingenuity and precarious resources.

In 2010 Brazil had about 14 metropolitan areas with population over one million. São Paulo had more than 19 million and Rio de Janeiro more than 11 million people. And yet, 80 percent of slum dwellers in Brazil live in metropolitan areas, according to IBGE (2000). The collection and disposal of solid waste is extremely poor in relation to the water and land pollution scenario. Sewage collection leaves much to be desired in the country - it serves 52.2 percent of municipalities and 33.5 percent of households according to IBGE (2000) - and some once-eradicated epidemics are making a come back (Saldiva et al. 2010). The pattern of investment in metropolitan construction projects shows the lack of integration between the actions of the municipalities that make up the metropolitan area, and some state governments have only sectoral metropolitan plans, and even these are rarely implemented. Not infrequently the urban orientation of a municipality is prejudicial to that of other municipalities. Macro-drainage, collection and distribution of treated water, transportation of cargo and passengers, sewage collection and treatment, housing, and land use and occupation are issues that require an integrated approach in the metropolis. Despite these concerns, the metropolitan issue is a kind of "limbo" in Brazil. There is no administrative integration and, what is worse, nobody seems to be interested in the subject.

\section{Metropolitan Regions: from the authoritarian centralization of the military regime to the liberal decentralization of the 1988 Constitution}

There is a virtual consensus among scholars, technicians and professionals on the precariousness of the legal framework of Metropolitan Regions (MR) in Brazil, which stems from the diversity of criteria - agreed upon in each state of the federation after the 1988 Constitution - for defining these regions. If during the dictatorial period this definition was imposed in an authoritarian manner by force of federal law (Complementary Law 14), which followed the 1967 Constitution, the 1988 Constitution transferred the prerogative to the scope of the various State Constitutions. The 35 Metropolitan Regions legally defined in 2010, plus three Integrated Economic Development Regions (known as RIDES) spanning more than one state, make up a heterogeneous group within 
which there are urban clusters of very different demographic, economic, social and political relevance.

The 1988 Constitution followed a democratic and decentralizing orientation - affirming the municipal autonomy, especially in relation to urban development - as a response to the dissatisfaction generated by the military regime's authoritarian manner of imposing the MR. But the fact is that none of the two manners has led to satisfactory results, although this difficulty lies more in the sphere of politics or power relations than in the lack of improvement of the legal apparatus itself. During the 1970s, the federal government defined nine MR, whose management was entrusted to a Deliberative Council made up mainly of representatives appointed by the federal and state governments (state governors, in turn, were appointed by the federal government). The mayors who were part of the MR could appoint only one representative tot the Deliberative Council or the Advisory Council, also established by the same law. This initiative, though undemocratic, led to the establishment of some of the most important metropolitan planning organizations, due in large part to the availability of funds for housing and urban infrastructure (Klink, 2009).

Let us remember how the Brazilian State addressed the metropolitan issue during the authoritarian regime, for the sake of explaining also why it was so under-addressed in the 1988 Constitution and in the 2001 Statute of the City 2001.

The Second National Development Plan (NDP) of 1974 provided for the creation of the Federal Housing and Urban Planning Service, which managed the Planning Financing Fund. These entities were succeeded by the Urban and Metropolitan Region Policy Commission, administrator of the Urban Development Fund and of the Urban Transport Fund, subsequently transferred to the Brazilian Company of Urban Transport. The subways of São Paulo and Rio de Janeiro, for example, date back to that period. Urban Planning gained much prestige and the Master Plans multiplied, fostered by federal government incentives. Studies on the Brazilian urban network and the need for a strong federal role in guiding the process of urbanization also proliferated, as shown in the pioneer study carried out by the Institute of Applied Economic Research (IPEA, 1974) on the National Urban Development Policy. ${ }^{3}$

Despite the significant production of National, Metropolitan and Municipal Plans as well as the institutional framework created by the dictatorial government, the fate of the cities remained virtually unchanged. However, the role of the state in that period was more effective than in the following decades, marked by the deregulation of public policies and the decline in public investment. The Financial Housing System (SFH) and its managing entity, the National Housing Bank $(\mathrm{BNH})$ were in fact the organizations that influenced the growth and pattern of Brazilian urbanization the most, by disseminating the middle class apartment and strengthening real estate businesses and the construction industry.

With social housing generally located outside of the urban fabric, the $\mathrm{BNH}$ 
and its financial system have not only contributed to segregate the lower income strata, but have also precluded the urban land market - boosted by housing financing resources from private savings (Brazilian Savings and Loan System - SBPE) and compulsory savings (Employees Dismissal Fund - FGTS) - from operating sustainably. As the central urban housing and investment entity, the $\mathrm{BNH}$, in general, did not follow the urban planning funded by the federal government itself.

But it must be recognized that sanitation, housing and urban transport have never, to date, recovered the level of investment of the 1970s. The National Sanitation Policy was guided by the National Sanitation Plan (PLANADA) and funded by the Financial Sanitation System (SFS), whose main source was the FGTS (Employees' Severance Fund). During the military regime, water and sewerage services were concentrated in state companies, leading to the establishment of strong public enterprises and weakening municipal autonomy. Federal loans were also used in coercively to break the resistance of municipalities, which resisted surrendering concession of the services to state companies (Maricato, 1984). The extension of the treated water network to metropolitan peripheries promoted by PLANASA succeeded in accelerating the downward trend of infant mortality rates, thus showing that some public policies did include some planning - albeit in an authoritarian manner - which is not common in the history of urban Brazil. Housing policy agents, the Housing Companies (COHABs) and companies or autarchies, then the agents responsible for implementing the sanitation policy, participated in the in the SFH and SFS.

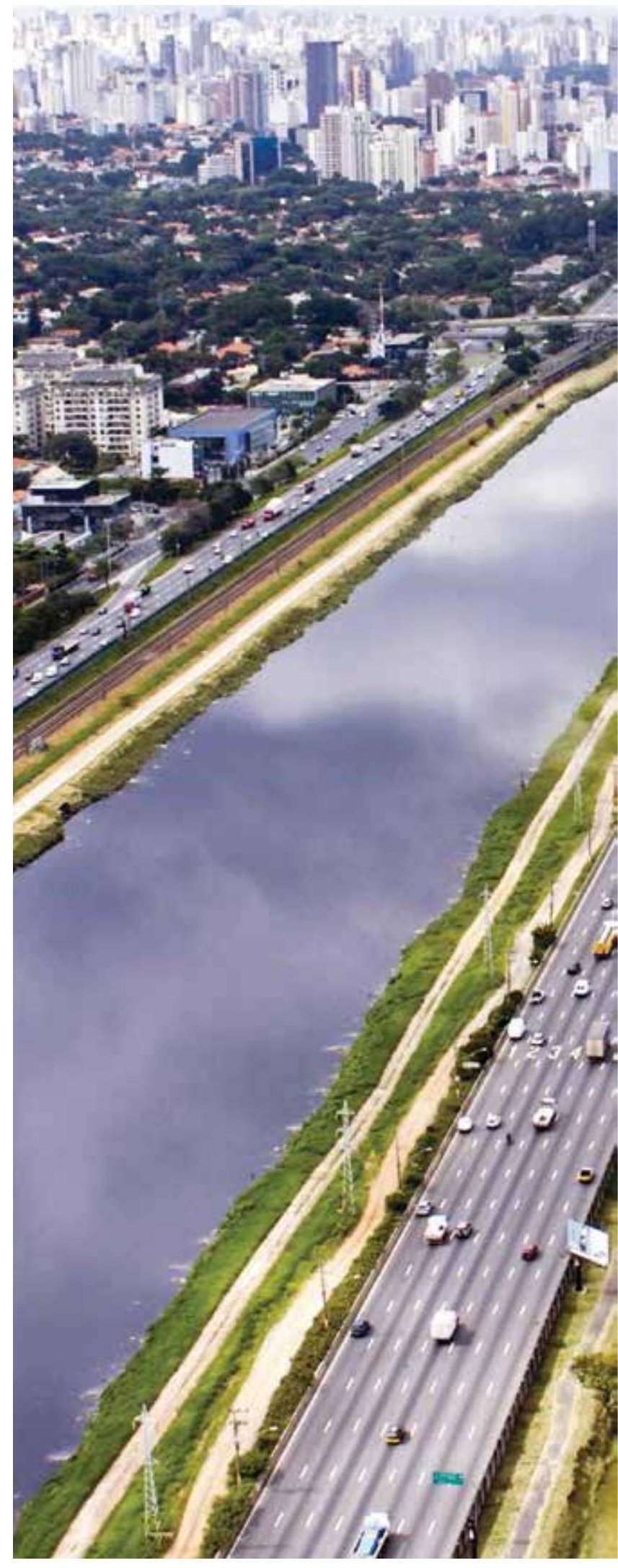

Estudos AvanÇADOS 25 (71), 2011 


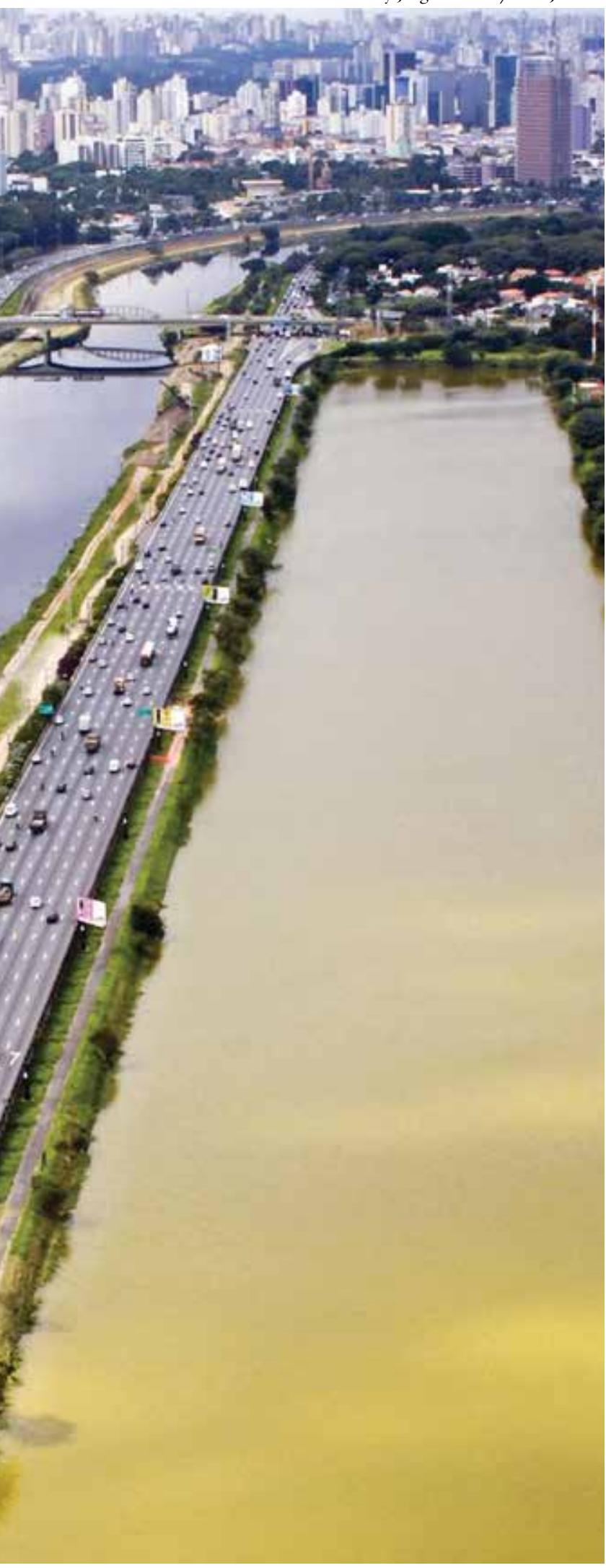

The role of the agents was defined centrally by the federal government forming, therefore a concentrated and centralized structure, which operated under the rules set by the federal government. Even the design of the housing complexes was replicated in different regions of the country, regardless of aspects such as the local weather and culture (Maricato, 1984).

Despite the concentration of wealth promoted by the dictatorial government, the metropolitan peripheries continued to be an area of opportunity for the masses that migrated to the cities, as the significant economic growth ensured opportunities for both formal and informal labor. For more than four decades of late industrialization - 1940 to 1980 - Gross Domestic Product (GDP) grew by more than 7 percent a year. At the same time, the country experienced high urbanization rates, concentrated especially in the metropolises, thus ensuring an abundant supply of cheap labor. Low-wage industrialization was matched by low-wage urbanization: self-construction of houses, illegal land occupation and horizontal growth of neighborhoods with no urbanization, whose occupation was made possible by the precarious conditions of road transport, which was indispensable for the workforce to commute.

In the early 1980s, investments in housing and sanitation and urban infrastructure works experienced a sharp drop due to the fiscal crisis.

View of the USP race course (right), and the Marginal Highway and Pinbeiros River (left). 
Public transport, sanitation and housing policies followed an erratic course thereafter. In the Collor administration sanitation companies went into decline for lack of funds and were subsequently (on the occasion of the federal government-IMF agreement in 1998) oriented towards privatization. ${ }^{4}$ Resolution No. 2521 of the National Monetary Council earmarked FGTS loans for the area of sanitation, as determined by the Ministry of Finance. Loans would be granted only upon the privatization of services. An attempt to establish a regulatory framework for the sector was Federal Law No. 199, agreed upon by the entities involved in the matter but vetoed in full by President Fernando Henrique Cardoso (FHC) in 1997. The "arm wrestling" of interests pro and against the privatization of the sanitation sector precluded the approval of a new regulatory framework - which finally happened in 2007 - and this area that is so fundamental to health, the environment and the economy remained undefined for more than two decades.

In early 2003, only six of the 27 state sanitation companies had not gone bankrupt or been closed down: SP, PR, DF, MG, ES and CE. The same fate awaited the COHABs, which were closed down during the Cardoso government. The urban transport policy followed the same Via Crucis, with the aggravating circumstance that investments were not resumed to the same extent as in sanitation and housing, with the creation of the Ministry of Cities in 2003. The Collor administration closed down the Brazilian Company of Urban Transport (EBTU), rendering federal actions in the sector meaningless. Other entities with the same duties were created and weaned off as the industry went into crisis, as evidenced by the increase in the proportion of household income spent on transport in Brazilian cities, and the drop in the number of users of mass transport. ${ }^{5}$

Despite showing one of the highest rates of urbanization in the world -84 percent in 2005, according to the IBGE - the Brazilian State virtually ignored the urban and metropolitan policy from the decline of the $\mathrm{BNH}$ in 1980 to the creation of the Ministry of Cities in 2003. If during the BNH days there were many construction projects that did not follow any explicit urban planning, with the Ministry of Cities we cannot say that this orientation has changed and that the Brazilian urban tragedy is being faced (Maricato, 2011). ${ }^{6}$

\section{Metropolitan Regions and metropolises in 2010: Changes and continuities}

Since the 1988 Constitution, the states have begun to define MR and RIDES based on their own criteria. In 2010 there were 38 clusters formed by 444 municipalities, involving 21 states plus the Federal District. They are: Belém (PA), Macapá (AP), Manaus (AM), Aracaju (SE), Agreste (AL), Cariri (CE), Fortaleza (CE), Greater São Luís (MA), João Pessoa (PB), Maceió (AL), Natal (RN), Recife (PE), Ride Petrolina/Juazeiro (BA/PE), Ride Teresina/ Timon (PI/MA), Salvador (BA), Southwest Maranhão (MA), Santos (SP), Belo 
Horizonte (MG), Campinas (SP), Greater Vitória (ES), Rio de Janeiro (RJ), São Paulo (SP), Vale do Aço (MG), Carbonífera (SC), Chapecó (SC), Curitiba (PR), Florianópolis (SC), Mouth of Itajaí River (SC), Lages (SC), Londrina (PR), Maringá (PR), Northern/Northeastern Santa Catarina (SC), Porto Alegre (RS), Tubarão (SC), Vale do Itajaí (SC), Goiânia (GO), DF RIDE (DF, GO and MG), Valley of the Cuiabá River (MT) (Observatory of the Metropolis, 2010). A public policy for the MR would hardly be satisfactory in view of the discrepancy between these clusters officially defined from such unequal criteria.

In search of a more homogeneous concept capable of providing a more coherent framework, the Observatory of the Metropolis $(2004,2010)$ developed in 2004 a study commissioned by the Ministry of Cities, with the aim to contribute to the definition of a policy for the MR. Building on criteria related to the integration between municipalities of MR, 15 clusters considered to be a metropolitan area according to this methodology were defined. They are:

Table 1 - Brazilian metropolitan areas - population IBGE/2010

\begin{tabular}{lc}
\hline Metropolis & Population \\
\hline São Paulo & $19,672,582$ \\
\hline Rio de Janeiro & $11,602,070$ \\
\hline Belo Horizonte & $4,882,977$ \\
\hline Porto Alegre & $3,960,068$ \\
\hline Brasília & $3,716,996$ \\
\hline Curitiba & $3,168,980$ \\
\hline Salvador & $3,353,704$ \\
\hline Recife & $3,688,428$ \\
\hline Fortaleza & $3,525,564$ \\
\hline Campinas & $2,798,477$ \\
\hline Manaus & $2,021,722$ \\
\hline Goiânia & $2,091,335$ \\
\hline Belém & $2,040,843$ \\
\hline Vitória & $1,685,384$ \\
\hline Florianópolis & 877,706 \\
\hline Total metropolitan areas & $\mathbf{6 9 , 0 8 6 , 8 3 6}$ \\
\hline Source: Obsry
\end{tabular}

Source: Observatory of the Metropolis $(2004,2010)$.

Some changes observed in the urbanization process in Brazil from the 1980s provide the basis for a reflection on the transformations that would be occurring in the metropolises and their role in Brazilian society (Carvalho et al., 2010; Observatory of the Metropolis, 2010). They are: a) medium-sized cities with population between 100,000 and 500,000 and cities with population above this range began to grow at higher rates than the metropolises, or above 
the national average; b) in turn, after centuries of urban growth concentration along the coasts, a relative reorientation of the migration/urbanization process was also observed in the period, and the highest rates were found in cities in the North and the Central-West regions - the sharp economic and demographic decline of the metropolis and even the possibility of a "demetropolization" phenomenon are mentioned; c) some evidence indicate an out-migration from metropolitan centers to municipalities in outskirts of metropolitan areas; d) the Southeast region experiences a fall in the ranking of Value of Industrial Transformation (VTI) in the country - from 80.7 percent in 1970 to 61.8 percent in 2005, impacting especially the main metropolitan areas of São Paulo, whose VTI fell from 43.5 percent in 1970 to 22.0 percent in 2005, while all other regions in the country rose in the ranking. The same applies to formal labor. ${ }^{7}$

While recognizing these changes - some of which are due to transformations in Brazilian capitalism that impact most of the territory besides the metropolises - the Observatory of the Metropolis reaffirms the concentration of power in the centers mentioned. A look at the complexity of the whole Brazilian urban network - which may include the polarizations of the metropolitan area in medium-sized cities - and the 1991, 2000 and 2010 Censuses show that the 15 metropolitan areas in question are increasing their share in the overall Brazilian population, although some of them show a relative drop in the total population, as is the case of São Paulo, Rio de Janeiro, Porto Alegre and Recife (Observatory of the Metropolis, 2010). In 2010 they concentrated a little over 69 million people, accounting for 36.2 percent of the overall population ( 34.9 percent in 1991 and 36.0 percent in 2000) and 56.5 percent of the urban population. And they were also responsible for 50.3 percent of Brazilian GDP and 55 percent of the value of industrial transformation.

\section{Some administrative cooperation attempts in metropolitan areas: an incipient scenario}

A proposal for the cities contained on an agenda that became known as Urban Reform emerged in the scope of the social struggle that opposed the dictatorial regime and won over democratic institutions. The enactment of the Statute of the City through Federal Law No. 10257 may have been the highlight of the achievements of this social movement. As already mentioned, metropolitan areas were not the subject of greater attention or detailing in the Constitution or in the Statute of the City, due to the heavy centralizing legacy that negatively impacted the debate. However, social forces mobilized amidst the rise of political participation, especially in the 1980s and 1990s, sought to open cooperative paths in the daily lives of governments. Several important actions in that period took the form of consortia - entities that voluntarily organized themselves to provide solutions to common problems such as the management of water resources, the final disposal of solid waste, the fight against unemployment and the decline in the industrial activity. 
Noteworthy is the Consortium of the Greater ABC Region, which during the 1990s gathered seven mayors from that region of São Paulo. The consortium relied on a relatively complex administrative structure to address specific and general issues, and for some time succeeded in incorporating representatives of labor unions, business associations, social leaderships, and the state government (Rolnik \& Somekh, 2004). The successful Consortium of the Greater $\mathrm{ABC}$ region did not seem to lack a legal and institutional basis, although the absence of a clear legal design for this type of collaboration was identified as an obstacle to its consolidation, and ultimately inspired the passing of a federal law, in 2005 known as the Public Consortia Law. When the debate on PublicPrivate Partnerships (PPP) derived from the neoliberal model was still high on the national agenda, a law was drawn up by initiative of the Secretary of Institutional Affairs, which brought together some of the former participants of public consortia. The law, which passed in Congress, aimed at providing legal basis for public consortia. But from mid-2005 the Urban Reform agenda and the political activism that followed began to lose political importance (Maricato, 2011), and the numerous experiences of the consortia did not show many cases that went beyond sectoral policies (Spink et al., 2009).

With respect to the institutionalization of metropolitan administrative entities, which in most cases are created and implemented from the top down, the scenario is not better; on the contrary. Thirty years after the creation of the MR, only seven have the "existence of specific, institutionalized and active metropolitan management structures which are developing some kind of public policy" (ibid, p.463). In general, the format used is that of creating entities: Development Agency, Metropolitan Fund and Development Council. The MRs that are part of this structure include: Santos, Campinas, Recife, Belo Horizonte, Vitória, João Pessoa, plus an interrupted experience in Natal. None of them presents a satisfactory experience of administrative integration, especially considering the central topic of control over land use and occupation that is related to the major problems experienced by metropolitan areas: social, environmental, sanitation, transport, drainage, health and security issues.

\section{Governance of metropolitan areas: The social, economic and envi- ronmental urgency and its political irrelevance}

Christian Lefebvre (2009) draws attention to the paradox between the growing relevance of the metropolis worldwide and its dwindling importance as a territory of politics, evidenced by the failure in the creation of metropolitan institutions. Therefore, it is not a Brazilian, but rather a global phenomenon, as shown by the author through examples from various parts of the world, notably the core countries of capitalism. The rivalry between national States, with the possible importance of metropolitan authorities and the prestige of local democracy or of communes, is pointed out by the author as factors of delegitimization of the metropolis. 
In Brazil, the "municipalist" tradition - which dates back to colonial times - recovered by the 1988 Constitution and reaffirmed by the parochial and pork barrel policies adopted by the executive and legislative branches, reinforces this localism that was encouraged in the 1990s by the World Bank and similar organizations (Vainer, 2000). State and federal governments prefer not to part with parochial policies: instead of streamlining investments based on territorial planning, negotiations around political support earmark the resources for some municipalities and not for others. There are programs that prioritize investments in MR such as the Growth Acceleration Program (PAC), in the area of housing and sanitation. There are state programs in the area of metropolitan transport, but they are sectoral programs and receive occasional investments.

The complex federative design of competencies related to urban and metropolitan development, which would imply federal, state and local cooperation, is compounded by the lack of perennial sources of metropolitan investment. This explains the amazing poor condition of public transport, which is neglected over the private car and road works (Maricato, 2011).

Other factors also contribute to derail administrative cooperation in metropolitan areas. The existence of poles with significant economic, political and cultural disparity also hinders this integration, to the extent that municipalities with higher tax revenues are not interested in redistributing part of their revenue. Finally, this list could go on and on to show that despite the urgency, no political force with significant presence in the Brazilian scene is interested in changing the course of the metropolis. The issue is in the limbo.

\section{Notes}

1 Among Brazilian authors featured in the book organized by Manuel Castells are Paul Singer, Fernando Henrique Cardoso, Lucio Kowarick, Cândido Ferreira de Camargo and Milton Santos. Among the foreigners who fueled the controversy is Aníbal Quijano, besides Castells himself.

2 See the chapter about " Formação e impasse do pensamento crítico sobre a cidade periférica" in Maricato (2011). The text draws attention to the progress achieved in the studies and practice of some municipal governments and also to their impasse starting from the mid-2000s.

3 This IPEA study, which proposes a public policy under the name of Política Nacional de Desenvolvimento Urbano, is part of a certain tradition of looking at the Brazilian urban network. It was followed by the 1985 document from the National Urban Development Council (CNDU) entitled Evolução da Rede Urbana no Brasil 19701980; by the 1999 text prepared by Ipea-Nesur/Unicamp-IBGE - Tendências e perspectivas da rede urbana do Brasil; by the document A nova geografia econômica do Brasil: uma proposta de regionalização com base nos polos econômicos e suas áreas de influência, Cedeplar/UFMG, 2000. In 2004, the Ministry of Cities (MCidades) commissioned several studies with the aim of developing the National Urban Development Policy (UNDP) and the National Policy for Metropolitan Regions. They are gathered in MCidades 2005 and MCidades/Fase/Observatório das Metrópoles, 2005 (digital 
version). Other partial or supplemented editions of this material were developed by the Ministry of Cities in 2008 (Cunha \& Quarry, 2008) and the Observatory of the Metropolis/ CNPq (2009) - Luiz Cesar de Queiroz Ribeiro (Org.) Hierarquização e identidade dos espaços urbanos. Rio de Janeiro: Letra Capital, 2009. See especially the first and second volumes organized by Rosa Moura and Jean Bitoun and others. The formulation of these national - urban and metropolitan - policies stopped when Olivio Dutra left the Ministry of Cities.

4 On the decision to centralize sanitation services in the hands of state companies, see the doctoral thesis submitted to the FAUUSP (Maricato, 1984). On government pressure in the 1990s, for privatization see: “A crise do setor de saneamento no Brasil. Oficina de Informações”. Report, special edition, Osasco, Year 2, n.15, November 2000.

5 See IBGE /CNTU survey for the period 1995/2002.

6 An analysis of the urban policy institutionalized by the Cardoso government can be found in Maricato (2003). For an assessment of the urban and housing policy during the mentioned period, see Azevedo \& Mares Guia (2007).

7 According to the lecture "Globalização e território: leitura a partir do Brasil “ delivered by Prof. Tania Bacelar at the Town Hall of São Paulo in May 2008.

\section{References}

ARANTES, O. et al. A cidade do pensamento único. Desmanchando consensos. Petrópolis: Vozes, 2000.

ARANTES, P. F. A interpretação marxista da cidade de São Paulo nos anos de 1970.

Revista Novos Estudos Cebrap, São Paulo, n.83, March 2009.

ASCHER, F. Metapolis ou l'avenir des villes. Paris: Odile Jacob, 1995.

AZEVEDO, S. de; MARES GUIA, V. R. Federalismo, atores e arranjos cooperativos nas Regiões Metropolitanas: possibilidades e limites para a inovação institucional. In: RIBEIRO, L. C. de Q.; SANTOS JUNIOR, O. (Org.) As metrópoles e a questão social brasileira. Rio de Janeiro: Revan, Fase, 2007.

BENKO, G.; LIPIETZ, A. Les region qui gagnent. Paris: Presses Universitaires de France, 1992.

BRANDÃO, C. Território e desenvolvimento. Campinas: Unicamp, 2007.

BRENNER, N. O que é a teoria crítica urbana. Revista eletrônica e-metrópolis, year 1 , No.3, Dec. 2010.

CÁCERES, G.; SABATINI, F. (Org.) Barrios cerrados. Santiago de Chile: PUC/Lilp, 2004.

CANO, W. Reflexões sobre o Brasil e a Nova (Des)ordem Internacional. Campinas: Unicamp, 1995.

CARVALHO, I. M. M. de. et al. Mudanças e permanências nas metrópoles: São Paulo e Salvador. Caderno CRM UFBA, Salvador, n.59, May/Aug. 2010.

CASTELLS, M. Imperialismo y urbanización en America Latina. Barcelona: EditorialGustavo Gilli, 1973. 
A sociedade em rede. São Paulo: Paz e Terra, 1999.

COBOS, E. P.; LÓPEZ, L. M. Presente y futuro de las metrópolis de America Latina. Cadernos Metrópoles Educ, São Paulo, n.18, 2nd half 2007.

CUNHA, E. M. P.; PEDREIRA, R. S. (Org.) Hierarquização e identificação de espaços urbanos. Brasília: Ministry of Cities, 2008. v.1.

Tipologia das cidades brasileiras. Brasília: Ministry of Cities, 2008. v.2. DAVIS, M. Planeta favela. São Paulo: Boitempo, 2006.

DINIZ, C. C. Desenvolvimento poligonal no Brasil: nem desconcentração, nem contínua polarização. Nova Economia, Belo Horizonte, v.3, n.1, Sept. 1993.

. A questão regional e as politicas governamentais no Brasil. Belo Horizonte: Cedeplar, Face, UFMG, 2001. (Discussion paper No.159).

FERREIRA, J. S. W. O mito da cidade global. Petrópolis: Vozes, 2007. HARVEY, D. Condição pós-moderna. São Paulo: Loyola, 1992.

. O novo imperialismo. São Paulo: Loyola, 2005.

HOLANDA, F. Apresentação. Cadernos da Metrópole Educ, São Paulo, No. 24, 2010. INSTITUTE OF APPLIED ECONOMIC RESEARCH - IPEA. Politica Nacional de Desenvolvimento Urbano. IPEA, 1974.

. Configuração atual e tendências da rede urbana do Brasil. IPEA-Nesur, Unicamp-IBGE, 2002.

KHAIR, A. Finanças públicas: financiamento do desenvolvimento urbano. Presented by the Council of Cities in July 2005. (Digital version released at the 2 nd National Conference on Cities. Brasília: MCidades, 2005). KLINK, J. J. A cidade região. Rio de Janeiro: DP\&A, 2001.

. Novas governanças para as áreas metropolitanas. Cadernos Metrópoles Educ, São Paulo, v.11, No. 22, July/Dec. 2009.

LEFÈVRE, C. Governar as metrópoles: questões, desafios e limitações para a constituição de novos territórios políticos. Cadernos Metrópoles Educ, São Paulo, v.11, No. 22, July/Dec. 2009.

MARCUSE, P. The enclave, the citadel and the ghetto: what has changed in the postFordist U.S. city. Urban Affairs Review, v.33, No. 2, Nov. 1997.

MARICATO, E. Indústria da construção e politica habitacional. São Paulo, 1984. Thesis $(\mathrm{PhD})-$ School of Architecture and Urbanism, University of São Paulo.

. Metrópole, legislação e desigualdade. Estudos Avançados, São Paulo, v.17, No. 48, May/Aug. 2003.

MARICATO, E. O impasse da politica urbana no Brasil. Petrópolis: Vozes. 2011. In press.

MATOS, C. A. de. Redes, nodos e cidades: transformação da metrópole latinoamericana. In: RIBEIRO, L. C. de Q. (Org.) Metrópoles entre a coesão, a fragmentação, a cooperação e o conflito. São Paulo: Perseu Abramo Foundation, 2004.

MOURA, R. Dinâmicas territoriais recentes: rupturas ou manutenção de tendências? Cadernos Metrópoles Educ, São Paulo, n.24, 2010. 
MOURA, R. et al. Diagnóstico sócio-econômico e da estrutura de gestão das Regiões Metropolitanas brasileiras. In: SEMINÁRIO INTERNACIONAL DESAFIO DA GESTÃO DAS REGIÕES METROPOLITANAS EM PAÍSES FEDERADOS. Brasília: Ministry of Cities, Chamber of Deputies, March 2004.

OBSERVATORY OF THE METROPOLIS. Análise das Regiões Metropolitanas no Brasil: construção de tipologias. Brasília: Ministry of Cities, 2004. (Digital version released at the 2 nd National Conference on Cities. Brasília: MCidades, 2005.)

. As metrópoles no Censo de 2010: novas tendências? Available at: <http://www. observatoriodasmetropoles.ufrj.br>. Access on 31 Jan. 2010.

REIS FILHO, N. G.; TANAKA, M. (Org.) Brasil, estudos sobre dispersão urbana. SãoPaulo: Fapesp, 2007.

RIBEIRO, L. C. de Q. (Org.) Metrópoles entre a coesão, a fragmentação, a cooperação e o conflito. São Paulo: Perseu Abramo Foundation, 2004.

ROLNIK, R.; SOMEKH, N. Governar as metrópoles: dilema da recentralização. In: RIBEIRO, L. C. de Q. (Org.) Metrópoles entre a coesão, a fragmentação, a cooperação e o conflito. São Paulo: Perseu Abramo Foundation, 2004.

SALDIVA, P. et al. (Org.) Meio ambiente e saúde, o desafio das metrópoles. São Paulo: Ex-libris, 2010.

SASSEN, S. As cidades na economia global. São Paulo: Nobel, 1998.

SAULE JUNIOR. N. Relatório de sistematização do “estado da arte" sobre a Cooperação Federativa no Brasil. Possibilidades legais de cooperação federativa para o desenvolvimento urbano. Presented by the Council of Cities in July 2005. (Digital version released at the 2 nd National Conference on Cities. Brasília: MCidades, 2005.)

SOUZA, M. L. de. O desafio metropolitano. Rio de Janeiro: Bertrand Brasil, 2000. SPINK, P. K. et al. Governança, governo ou gestão: o caminho das ações metropolitanas. Cadernos Metrópoles Educ, São Paulo, v.11, n.22, jul./dez. 2009. UN-HABITAT. The state of the world cities. London: Earthscan. 2010.

VAINER, C. Pátria, empresa e mercadoria. Notas sobre a estratégia discursiva do Planejamento Estratégico Urbano. In: ARANTES, O. et al. A cidade do pensamento único: desmanchando consensos. Petrópolis: Vozes, 2000.

. As escalas do poder e o poder das escalas: o que pode o poder local? CadernosIppur-UFRJ, n.2, 2001.

VELTZ, P. Mondialization. Villes et territoires. L'économie d'archipel. Paris: PressesUniversitaires de France, 1996. 
ABSTRACT - Despite their economic, political, social, demographic, cultural, territorial and environmental importance, there is a significant lack of government in the Brazilian metropolises, evidenced by the incipient initiatives of intermunicipal and federative administrative cooperation. This article analyses the structural changes - in the process of urbanization/metropolization - due to the productive restructuring of global capitalism, and on a national scale it analyzes the change in the institutional framework - legal/political - which went from concentrator and centralizer during the Military Regime, to decentralized and emptied, after the 1988 Constitution. The downturn observed in social policies during the 1980s and 1990s, notably in transport, housing and sanitation, besides the dismantling of metropolitan agencies, has led our cities to the trivialization of urban tragedies. Despite its urgency, the metropolitan issue does not sensitize any political force or institution which assigns it a prominent place on the national agenda.

KEYWORDS: Metropolitan areas, Metropolises, Metropolitan issue, Government collaboration, Misrule.

Erminia Maricato is an Urban Planning professor at USP and member of the editorial board of the journals Justice spatiale/ Spatial Justice, Université de Nanterre; Revista Brasileira de Estudos Urbanos e Regionais (Anpur); Cadernos da Metrópole; Observatory of the Metropolis/Educ/Ippur UFRJ; Revista Urbe- PUCPR; and Key Speaker at the Social Architecture Forum. Ankara, Turkey, 2010. @- erminia@usp.br Received on 11 Feb. 2011 and accepted on 23 Feb. 2011. 